\title{
Кагарлицкая С.Я.
}

\section{Неоклассик-авангардист Э. Ионеско}

в Московском театре на Таганке. Культурные универсалии

\author{
в художественно-эстетических практиках
}

Аннотация: Статья посвящена театральной интерпретации пьесы «Король умирает» классика французской абсурдистской драмы Эжена Ионеско на сцене Московского театра драмы и комедии на Таганке. Премъера 2012 г. Режиссер-постановщик знаменитый польский режиссер Кшиштоф Занусси. В главной роли - народный артист России Валерий Золотухин, сыгравший в спектакле свою последнюю роль. Спектакль был снят из репертуара, но остался открытым вопрос о мере взаимопонимания со зрителями, к которым он был обращен в надежде на соавторство. Автор статьи акцентирует внимание на том, как театр, опираясь на накопленный за века широкий арсенал сценических средств коммуникации, стремился помочь зрителям выйти за пределы «частного случая» в пространство общечеловеческого. Внимание привлечено к современному поиску универсального языка искусства как способа вовлечения зрителей в диалог, построенный на использовании таких культурных универсалий, как время, пространство, вера, дом, любовъ и т.д. - вечных экзистенциальных констант человеческого бытия, и, что не менее важно, - на перенесении в спектакле акцента со слова на визуальный ряд. Режиссер спектакля К.Занусси переосмыслил концепцию «абсурда» как жанра, и преодолел характерную для постановок 196о-х годов прошлого века безысходность. Трагический финал становился началом освобождения духа, он таил в себе надежду. Главной темой спектакля стало исследование способности отдельного человека ориентироваться в мире, если «культура больше не образует осмысленной истории, а переживания и события не могут быть включены в органическую смысловую взаимосвязь поколений культуры» (П. Козловски). Пьеса неоклассика-авангардиста открывала дорогу и для подобного прочтения.

Review: The article is devoted to the theatrical interpretation of Eugene Ionesco's play 'Exit the King' that was first staged at Taganka Theatre in Moscow in 2012. The play was directed by a famous Polish film director Krzysztof Zanussi and the major part in the play was played by Valeri Zolotukhin, the People's Artist of Russia, who played his last role in that play. Later the play was removed from the repertory but the question about the mutual understanding with the audience was left unanswered. The author of the present article focuses on how the theatre, based on a wide range of theatrical communication tools that had been accumulated for centuries, tried to help the audience to stand above the 'isolated situation' and get closer to universal human values. The author draws attention to the contemporary search for the universal language of art as a method of involving the audience into the dialogue built upon the principle of using such cultural universals as time, space, faith, home, love and etc., i.e. eternal existential constants of human existence and, which is equally important, upon the principle of shifting the emphasis from the word to the visual image in the play. The stage director Krzysztof Zanussi rethought the concept of 'absurdity' as a genre and overcame the atmosphere of despair which was typical for plays back in the 196oth. The tragic ending symbolized the release of spirit and therefore gave hope. The main theme of the play was the study of an ability of an individual to orient himself in the world when 'culture does not provide a meaningful history and emotional experience and events cannot be included in the organic relationship between cultural generations' (P. Kozlowsky). The play of Eugene Ionesco as a neo-classicist and avant-gardist showed the path to such interpretation as well.

Ключевъе слова: Театр абсурда, культура, культурные универсалии, интерпретация, коммуникация, миф, герой, визуальный ряд, зритель, диалог.

Keywords: Theatre of the Absurd, culture, cultural universals, interpretation, communication, myth, hero, visual imaginary, spectator, dialogue. 


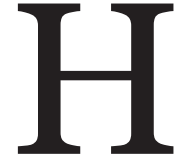
ачало дня. Поднимается флаг. Секретарь торжественно и почтительно представляет короля, обеих королев, доктора и служанку, в утренних халатах быстро пересекающих сцену. Идет театральная репетиция. Через минуту преобразившиеся они неспешно выйдут на сцену, чтобы разыграть спектакль-церемонию под названием «Король умирает». «Этот бал будет проходить в интимной обстановке, - доверительно сообщит первая жена короля Маргарита. - Нужно, чтобы все прошло достойно». И, обращаясь ко второй жене короля Марии, добавит: «Вы тоже сыграете свою роль».

На сцене Homo Faber в просторном кабинете с дорогой мебелью. В глубине - советник с портфелем. По диагонали от него, ближе к публике - секретарь с микрофоном и ноутбуком. Король Беранже I приветлив, энергичен. Он словно с картинки глянцевого журнала: элегантный символ власти, богатства, славы. Вспоминается портрет «Елизаветы II» Энди Уорхола: корона, бриллианты, орден. Но на длинном письменном столе двое песчаных часов: время и вечность вступили в соревнование. Королю Беранже объявили, что он умрёт в конце спектакля, через полтора часа.

Поговорка «Пока гром не грянет, мужик не перекрестится» как нельзя лучше передает смысл ситуации: универсальной и переживаемой каждый раз, как только твоя, личная. Зеркало, в котором привык видеть себя преуспевающим, сыграло с тобой шутку. И это тоже универсальная ситуация, берущая начало в античном мифе об Эдипе и трагедии Софокла «Эдип-царь». Классицистские единства со считанными фигурами мизансцен, строгой и точной фронтальной планировкой, минимальным реквизитом фокусировали внимание на стирании грани между лицом и масками персонажей, контрасте между самопрезентацией и хаосом разорванного сознания. Театр предлагал двойную игру, спектакль в спектакле.

Камерный на первый взгляд сюжет разворачивался, подобно сжатой пружине, обнаруживая множество внутренних связей с дальними и ближними предшественниками по культурному процессу. Единая сцена с её тяготением к рациональному возвращала к жизни эпические элементы классицистской драмы. При смене ракурса те же самые персонажи и детали, как в калейдоскопе, обретали замечательную способность объединяться в новые пары и сюжеты и создавать разные образы пространства жизни человека. Рабочий кабинет - он же тронный зал короля Беранже I - со следами обветшания напоминал большой серый каменный бункер, грот или пещеру, куда спускаются с помощью узких дверей - лифтов. Это холодное пространство наглухо закрыто от окружающего мира. Изоляция и выключенность из временного потока объясняют иллюзорность представления Беранже о жизни и о себе, великом и бессмертном. Вневременному мышлению чужда логически последовательная цепь причин и следствий.

Даже в поисках выхода во внешний мир за спасением герой, как в зеркале, видит только свое отражение. Пещера-ловушка превращается в образ подполья внутренней жизни героя, эгоистической погруженности в себя. В конце спектакля, смутно ощущая в себе «другого», возможно, прежнего, он захочет понять: «Во мне зеркало. Оно отражает мир и жизнь, которая уходит. Или, может, я - зеркало всего?» Зеркало как метафора творчества и универсальный культурный символ отразило в частном картину целого.

Лифтовые двери на вход и выход в многозначной символике единой сцены обозначили границу между тем, что «вне», и тем, что «внутри» в пространстве жизни персонажей. В первый лифт входит первая жена короля, она же смерть, в другой лифт выходит жена любимая - жизнь. Одна в белом строгом костюме - цвете траура у многих народов, другая в красном легком платье символического цвета жизни, огня, любви и красоты. Эти же узкие двери на последнем этапе жизни героя могли символизировать обряд трудного перехода от мирского способа бытия к священному и затем от жизни к смерти. Время и вечность вступили в конфликт. Доминирует современность, но «вечные» категории помогают поднять «частный случай» к обобщению. А элементы «репетиции» и «сцены на сцене» - театральных жанров, неплохо послуживших в XVII-XVIII веках комической музе, начинают служить музе Трагедии, как они 
уже послужили французской интеллектуальной драме середины XX века. И так же, как в «Антигоне» Жана Ануя, функцию античного хора, словно бы заимствованного у античной трагедии, выполняют актеры, «выходящие» из основной роли и становящиеся комментаторами происходящего.

Театр говорил своим собственным языком - языком пространства, которое расширилось и одновременно уплотнилось, симметричной композиции, сменой крупного и общих планов, как в кино. Он сочетал тьму и прорезающий её луч света, как в живописи и фотографии. Кшиштоф Занусси и автор идеи сценографии художник Ева Старовойска включили в светоцветовую партитуру спектакля серый, багровый, синий цвета с их традиционной многозначной символикой, чтобы эмоционально окрасить восприятие разных этапов внутренней жизни героя и помочь зрителю увидеть «Внутреннее во Внешнем» (выражение В.В.Кандинского). Они устанавливали также связь между цветом и формой. Направленный синий цвет подсвечивал в форме круга или квадрата (имеющих внутреннее содержание) пространство героя на сцене и этим устанавливал символические границы между ним и остальными игроками.

Разные образы единой сцены визуально формировали многоликую картину, подобно тому, как «в полотнах Рембрандта живописная система цветовых и световых явлений образовывала, по сути, самостоятельную сторону реального мира»ํ. В XVII веке, к которому в ремарках не раз привлекал внимание Э.Ионеско, художники добились максимального зрительного впечатления в сочетании с умозрительным представлением. Их опыт, усвоенный современным театром, давал возможность зрителям сделать то, что недоступно персонажам: в процессе восприятия спектакля связать причины со следствиями, а также ощутить, что король Беранже I и его окружение - универсальные субъекты, как сказал бы философ Э.Кассирер. И добавил бы, что «не человечество должно быть объяснено через человека, а человек через человечество». Такую основу философ «усматривал в социологической и исторической мысли». «Познать себя, - соглашался он с Контом, значит познать историю»².

\footnotetext{
${ }^{1}$ Алпатов М. Композиция в живописи: исторический очерк. М., 1940. С.62.

${ }^{2}$ Кассирер Э. Человек и культура: Хрестоматия по истории философии: [в 2 т.] Т. 2. М., 1994. С. 92-93.
}

Автор пьесы, неоклассик-авангардист, тоже убеждён: «Настоящее искусство, называемое авангардистским или революционным, это такое искусство, которое, дерзко противопоставляя себя своему времени, проявляет себя именно как неактуальное. И проявляясь как неактуальное, такое искусство соединяется с универсальной и всеобщей основой ${ }^{3}$.

Ионеско называют королем подтекста. Зрителям самим предлагалось восстанавливать разрушенные связи между словом и смыслом, собирать из осколков более или менее целостную картину сознания персонажей, не способных обнаружить глубину пропасти, разделяющей «две ситуации существования, принимаемые человеком в ходе истории: мирское и священное» ${ }^{4}$. Сущностной характеристикой участников игры служит их отношение ко времени, к взаимоотношениям с природой и к содержанию таких универсальных понятий, как дом, семья, любовь, труд.

Классицистская эстетика с ее тягой к контрастам открывала большие возможности для сравнения. Сдержанная учтивость Маргариты (Л. Селютина) и нежная пылкость Марии (И. Линдт), справа и слева сидящих от короля, демонстрировали конфликт разума и чувства, их несовместимость, но столь явная конфронтация, чем дальше, тем больше помогала расслышать вариативное развитие одной темы. Первая жена бесстрастно, без тени обиды или боли припоминала королю, как, добиваясь бессменной власти, он избавлялся от своих и её братьев, всей родни, друзей и их семей, скота, как выжег их земли, как проиграл все войны, разорил страну и стерилизовал население, как сбежали уцелевшие. Король не сопротивлялся обвинениям, но держался подальше от нее, повинуясь инстинкту. От неё, такой здравомыслящей, исходил вполне ощутимый холодок чего-то застылого, мертвящего, лишенного трепета живой жизни. Иное дело молодая жена, жизнь с которой вечный праздник в честь всего на свете. Она не давала королю отвлечься от карнавалов и бесчисленных балов и страдать от их однообразия. Но король и её инстинктивно оттолкнул, когда вспомнил «добрую, умную» затравленную кошечку: «Она любила меня, единственная». Счастливая улыбка впервые появлялась на его лице. Жены зеркально отразили друг друга. Оппозиция уничтожалась. В спальне коро-

${ }^{3}$ Ионеско Э. Как всегда - об авангарде // Как всегда об авангарде. М., 1992. С. 131.

${ }^{4}$ Элиаде М. Мирское и священное. М., 1994. С.19. 
ля паутина, большая трещина прошла по всей стене тронного зала, не слышно детских голосов. Заимствованный у романтиков прием двойничества (две жены вместо одной) свидетельствовал еще и о смерти индивидуального, неповторимого.

Секретарь Короля, он же менеджер по связям с народом, по совместительству Страж. В древних мистериях - это имя Охранителя порога. Его перевёртыш торжественно сообщал в микрофон обрывки фраз Короля, обнажая пропасть антиобщения.

Новые возможности контрастов как приёма открывал сказочный список профессий Советника короля: доктор, бактериолог, астролог и палач. Так, вероятно, можно символически обозначить еще и этапы почти трёхсотлетней биографии короля - его в определенном смысле двойника. Король был палачом, о чем вспоминала жена. Вместо скипетра в его руке и сейчас кинжал. Беранже I и его жены часто и много говорят о своей связи с макрокосмом как о реальном религиозном переживании. Прошлый опыт сохранил память о том, что вся природа проявляется как космическое священное пространство. Но их слова не могут быть наполнены смыслом, так как не отражают никаких реальных связей. Язычник Беранже умоляет солнце спасти его при том, что дворец без окон закрыл дорогу небу, горизонту, солнцу и звездам. А в королевских владениях «трескается земля, природа гаснет» и «даже салат не растёт».

Голос каждого персонажа эхом отзывался в Беранже, словно встраиваясь, как тот или иной фрагмент, во внутренний монолог многоликого героя, принадлежащего не только человеческой истории и культуре, но своему времени и своему типу общества и культуры. Жены, доктор, страж, служанка символически обозначили ипостаси его разорванного сознания, спорящие друг с другом, как жизнь и смерть, как Страж и глашатай, как доктор и палач в одном лице. Но именно нестабильность сознания и перепады чувств героя создавали «текучесть» образа и этим «возвышали» Короля «над собой». Сильный и подвижный темперамент Валерия Золотухина, способность чувствовать и передавать контрастность и многообразие оттенков комических и трагических красок, его человеческая значительность разрушали однозначное восприятие героя, упоённого видимостью Власти и Славы.
Восхищала сдержанность его коллег. Ради возможности показать целое через соотношение частей они не демонстрировали самих себя. Хорошо знакомое актерам на Таганке искусство «светотени» иллюзию создавало и разрушало. Маски (особенно женских персонажей) остранялись спонтанными реакциями, сквозь которые проглядывали лица. Единая сцена и игра актеров представляли диалектическое единство: они достоверны и условны одновременно. Благодаря этому достигалось единство двух уровней действия. Сквозь наглядный фарсовый «бал» - сюжетный остов, уверенно ведущий к финалу, пробивался глубинный уровень действия - путь самопознания героя от маски к лицу. И это был путь героя трагедии.

Неоднозначность Беранже I заявляла о себе при его первом появлении в тронном зале босиком с ботинками в руках («ноги болят»), что вызвало шок придворных. И эта определенная мера естественности как производной от «цельности» - такая же объективная реальность, как и законы внешнего мира, которые он принял и по которым живет. Этот конфликт и составил основу трагедии.

Советник - он же доктор-палач по ходу игры торопил Короля с уходом, его ждут другие пациенты. Руководившая церемонией королева Маргарита успокаивала. «Необходимо соблюдать церемонию прощания. Надо, чтобы все произошло пристойно, чтобы была победа, триумф. Их давно не было».

Игра ведется со знанием придворного этикета. Театральные маски, похоже, давно освоены, заученные тексты декламируются в несколько утрированной традиции театра представления. Это Беранже I путается в ворохе своих прежних героических лиц и масок. Отзвуки голоса из глубины веков («Зачем я родился, если родился не навсегда») сменяют обрывки знакомых фраз Гамлета, короля Солнце... других литературных и исторических персонажей. Их перекрывают истерические выкрики фюрера... Короля охватывает страх и ужас. Но «программа должна быть выполнена от точки до точки, - объявляет королева Маргарита. - Церемония начинается». Борьба за власть - безжалостный, но эпизод в череде будней. Смерть перестала быть событием.

Энди Уорхол много раз возвращался к одному и тому же сюжету: плохо освещенной камере смертника с электрическим стулом. Графический лист, разделенный пополам, 
дважды повторял одну сцену: смертник с мешком на голове перед казнью. Чаще в камерах у него стулья оставались незанятыми. Один стул, потом снова два и затем «Пятнадцать электрических стульев, плавающих в голубой серебристой пустоте». Страх смерти, ужас перед неотвратимостью наказания или стремление осмыслить свой Путь и обрести надежду на спасение?

Кульминационные сцены спектакля связаны с поисками ответов на эти же вопросы. Театр сталкивал две возможные, контрастные по сути модели преодоления тупика. Первый путь - привычный - поиск внешних опор. Актёрствуя, король обращался с требованием к народу: «Пусть меня спасают». Обвинял родителей, время. Желая быть услышанным, король всё громче протестовал: вчера еще здоровый и молодой, он не хочет уйти в безвестность забытым, вычеркнутым из истории. Король в панике: «Может, это всё неправда?» «Я умираю. Вы слышите? Я хочу сказать, что я умираю, но не могу это выразить. У меня получается всё слишком литературно». Чужие слова, «литература переполняет», «опустошает». «Это и есть литература, - отмахивалась Маргарита. Я думала, он скажет несколько афоризмов. Мы припишем ему красивые слова». «Он будет жить в ней до последней минуты. Жизнь - только повод для литературы», - поправлял доктор, обеспокоенный неожиданной трезвостью суждений пациента и реакцией взбунтовавшегося, «сумасшедшего» сердца. Пора заканчивать игру.

И тогда от безысходности, сидя на авансцене в инвалидном кресле в луче света среди тьмы, Беранже, словно он тихо стонет, просит научить его примирению, и, обращаясь к бесчисленным ушедшим, просит утешения и братской помощи в том, чтобы перейти тот порог, что они перешли. Сцена приобщала к древнему ритуалу, проводимому в состоянии транса, к которому присоединились остальные. Это было нечто объединяющее, сохранившееся в генетической памяти помимо их воли и сознания. В ритуале «присутствовало нечто большее, чем он сам, а именно - присутствие Божественного». Близость смерти, кризис вызвали в нём ощущение движения времени. «Стоячее» время оказалось лишь частным случаем космического времени, причем аномальным.

Беранже не очень понимал, где он. В луче света на темной сцене остались только он и сиделка, она же служанка-сиделка Джульетта (Т.Сидоренко). Он больше не испытывал страха, он его не помнил, как и того, что он король. К нему вернулось чувство ценности человека как такового, пронзило острое чувство жизни с ее красками, запахами, чудом видеть голубое небо над головой и интересом к жизни другого - единственного сочувствующему ему человека - служанки. Лицо Золотухина освещала счастливая улыбка. Он шутил, вспоминал пиршество красок на овощном рынке, представлял, какую радость могут доставлять обычные вещи: жареная морковь, сама возможность жить, дышать, ходить за покупками, просыпаться по утрам. Он старался не думать о пауках в спальне, но не мог...

«Его жизнь была короткой прогулкой по цветущей аллее. Несбывшееся обещание, угасшая улыбка», - ностальгически произнесла чьи-то красивые и печальные слова королева Мария. И, выйдя из роли, деловито направилась к лифту.

В финале спектакля одинокий герой покинул замкнутое пространство бункера. Он шел по печальной дороге среди развалин. Это был не ад. Герой вышел в мир, который он оставил после себя: некогда прекрасный город, превращенный в руины.

Нечто подобное можно увидеть на холсте из серии «Оборотная сторона» (1981) Энди Уорхола. Изображения Мерилин Монро на черном фоне с яркими вспышками и полосами напоминают рентгеновский снимок. Художник изобразил изнанку жизни звезды - кумира миллионов, жизни, полной разочарований.

Сравнения всплывают автоматически. Драматург и художник принадлежат одному времени. Объект их внимания - потребители попкультуры: их ценности, нормы, мифология, люди с клиповым сознанием, их страхи, одиночество...

Спектакль с персонажами-марионетками, и при этом такими узнаваемыми, стремился приобщить к пониманию того, что утрата культурного контекста и утрата самобытности человека сопутствуют друг другу. Безграмотный король Беранже, не помнящий родства и без мыслей о будущем, оказывался перевёртышем королевы Маргариты, хотя ей услужливая память всегда подсказывала готовые рецепты из прочитанных книг или сыгранных ролей. Её спокойная уверенность, что «всё должно быть сохранено в памяти, но без воспоминаний» иллюзию оппозиции уничтожала. Культура в роли кладбища смыслов соз- 
давала ситуацию, округлую как орех: в ней все взаимозаменяемы как части одной матрёшки.

Некоторые критики сочли неудачной идею режиссера отказаться от понимания абсурда как жанра с преобладанием фарсового начала, блеска языковой игры, который бы в острогротескной манере отразил распад языка как средства коммуникации. Но этот театр, возможно, уже принадлежит истории. У него есть свои классики. И Эжен Ионеско - один из них. Тем более, что за минувшие полвека многое изменилось. Эксперимент становился привычным. Авангард превращался в стиль, переместился с «обочин» театральной жизни в сердцевину театрального истеблишмента. Распад языка в «обществе спектакля» (выражение Ги Дебора) для многих стал нормой. Еще двадцать с лишним лет назад режиссер Занусси, поставив пьесу «Король умирает» Э. Ионеско в Мюнхене, решил двигаться дальше. Он выбрал другую стратегию - абсурд как тема и структурный принцип «отражения вселенского хаоса». Пьеса неоклассикаавангардиста Э. Ионеско открывала дорогу и для подобного прочтения. Так преодолевалась характерная для постановок 1960-х гг. безысходность. Трагический финал становился началом освобождения духа. Он таил в себе надежду: «Сейчас не до и не после, а в данный момент в темноте брезжит свет» (П. Брук).

«Интерпретация - введение смысла, а не его объяснение» (Ф. Ницше). Спектакль театра на Таганке восстанавливал полноту восприятия человека, который эту полноту утратил. Отнюдь не безвинного страдальца, но человека. Широкий арсенал сценических средств коммуникации, накопленный за века, театр привлекал, чтобы помочь зрителям выйти за пределы «частного случая» в пространство общечеловеческого. За этим стояла неумирающая надежда художников и философов, что, становясь художественной, идея обретает жизненность. Получая реализацию в спектакле, искусство означает «приращение бытия. Оно не столько указывает на что-то, сколько содержит в себе то, на что указывает» 5 .

В социокультурной реальности, которой мы принадлежим, «визуальный поворот»

${ }_{5}^{5}$ Гадамер Г.-Г. Актуальность прекрасного // Актуальность прекрасного. М., С.3о2. сменил «лингвистический». «Я конкурирую с кино, - говорил на встрече с читателями прозаик Владимир Маканин. - Я стремлюсь к изобразительности, соперничающей с кино. Я даю штришок, чтобы еще глаз замер, а не только голова. Это не записанный изобразительный ряд. Это более сложное искусство. Человек формируется не только на эстетике языка». Разговор по сути дела об одном и том же. Разница в выборе ракурса, который каждый раз с новой точки зрения обозначает, хоть и не новую, но существенную проблему: зрелищные виды искусства вбирают в себя элементы общекультурного осмысления жизни. В произведениях разных его видов легко заметить сходный социологический, философский, культурологический подход к изображаемым жизненным процессам, к динамике происходящих изменений. Мы свидетели не нового, но существенного процесса в культуре: стремления обогатить односторонние формы познания их взаимным сближением. Этот процесс свидетельствует и о сильных интеграционных тенденциях, связанных также с осознанием необходимости соединения повседневности и культуры. В художественной практике это выражается в смене установки воспитания на примере на установку самодетерминации. «Индивидуальная самость, задача самообретения во все более стремительно изменяющемся социальном и природном мире - такова культурная тема современности» ${ }^{6}$ " Но для отдельного человека ориентация становится почти невозможной, - обращал внимание немецкий социолог, философ и экономист Петер Козловски, - если культура больше не образует осмысленной истории, а переживания и события не могут быть включены в органическую смысловую взаимосвязь поколений культуры »7.

P.S. Из интервью режиссера спектакля Кшиштофа Занусси: «Для меня вообще роль искусства, роль кино - это помогать людям глубоко посмотреть на свою собственную жизнь и жизнь общества. И понять других. Потому что мы ленивые, мы понимаем себя, а других не понимаем» ${ }^{8}$.

\footnotetext{
${ }^{6}$ Козловски П. Культура постмодерна. М., 1997. С. 86. ${ }^{7}$ Козловски П. Там же. С. 86.

8 Занусси К. Программа спектакля «Король умирает» Московского театра драмы и комедии на Таганке. М., 2012.
} 


\section{Библиография:}

1. Алпатов М. Композиция в живописи: исторический очерк. М., 1940.

2. Брук П. Нити времени. М., 2005.

3. Гадамер Г. - Г. Актуальность прекрасного // Актуальность прекрасного. М. 1991.

4. Ионеско Э. Носорог. Пьесы и рассказы. М., 1991.

5. Ионеско Э. Как всегда в авангарде // Как всегда в авангарде. М., 1992.

6. Занусси К. Программа спектакля «Король умирает» Московского театра драмы и комедии на Таганке. М., 2012.

7. Кассирер Э. Человек и культура // Хрестоматия по истории философии: [в 2 т.] Т.2. М.1994.

8. Козловски П. Культура постмодерна. М., 1997.

9. Пави П. Словарь театра. М., 1991.

10. Элиаде М. Мирское и священное. М., 1994.

11. Щупленков О.В., Щупленков Н.О. Национально-культурная идентичность в контексте философской традиции диалога культур // NB: Философские исследования. - 2013. - 10. - С. 183 - 244. DOI: 10.7256/23060174.2013.10.8848. URL: http://www.e-notabene.ru/fr/article_8848.html

\section{References (transliterated):}

1. Alpatov M. Kompozitsiya v zhivopisi: istoricheskii ocherk. M., 1940.

2. Bruk P. Niti vremeni. M., 2005.

3. Gadamer G. - G. Aktual'nost' prekrasnogo // Aktual'nost' prekrasnogo. M. 1991.

4. Ionesko E. Nosorog. P'esy i rasskazy. M., 1991.

5. Ionesko E. Kak vsegda v avangarde // Kak vsegda v avangarde. M., 1992.

6. Zanussi K. Programma spektaklya «Korol’ umiraet» Moskovskogo teatra dramy i komedii na Taganke. M., 2012.

7. Kassirer E. Chelovek i kul’tura // Khrestomatiya po istorii filosofii: [v 2 t.] T.2. M.1994.

8. Kozlovski P. Kul'tura postmoderna. M., 1997.

9. Pavi P. Slovar' teatra. M., 1991.

10. Eliade M. Mirskoe i svyashchennoe. M., 1994.

11. Shchuplenkov O.V., Shchuplenkov N.O. Natsional'no-kul'turnaya identichnost' v kontekste filosofskoi traditsii dialoga kul'tur // NB: Filosofskie issledovaniya. - 2013. - 10. - C. 183 - 244. DOI: 10.7256/23060174.2013.10.8848. URL: http://www.e-notabene.ru/fr/article_8848.html 